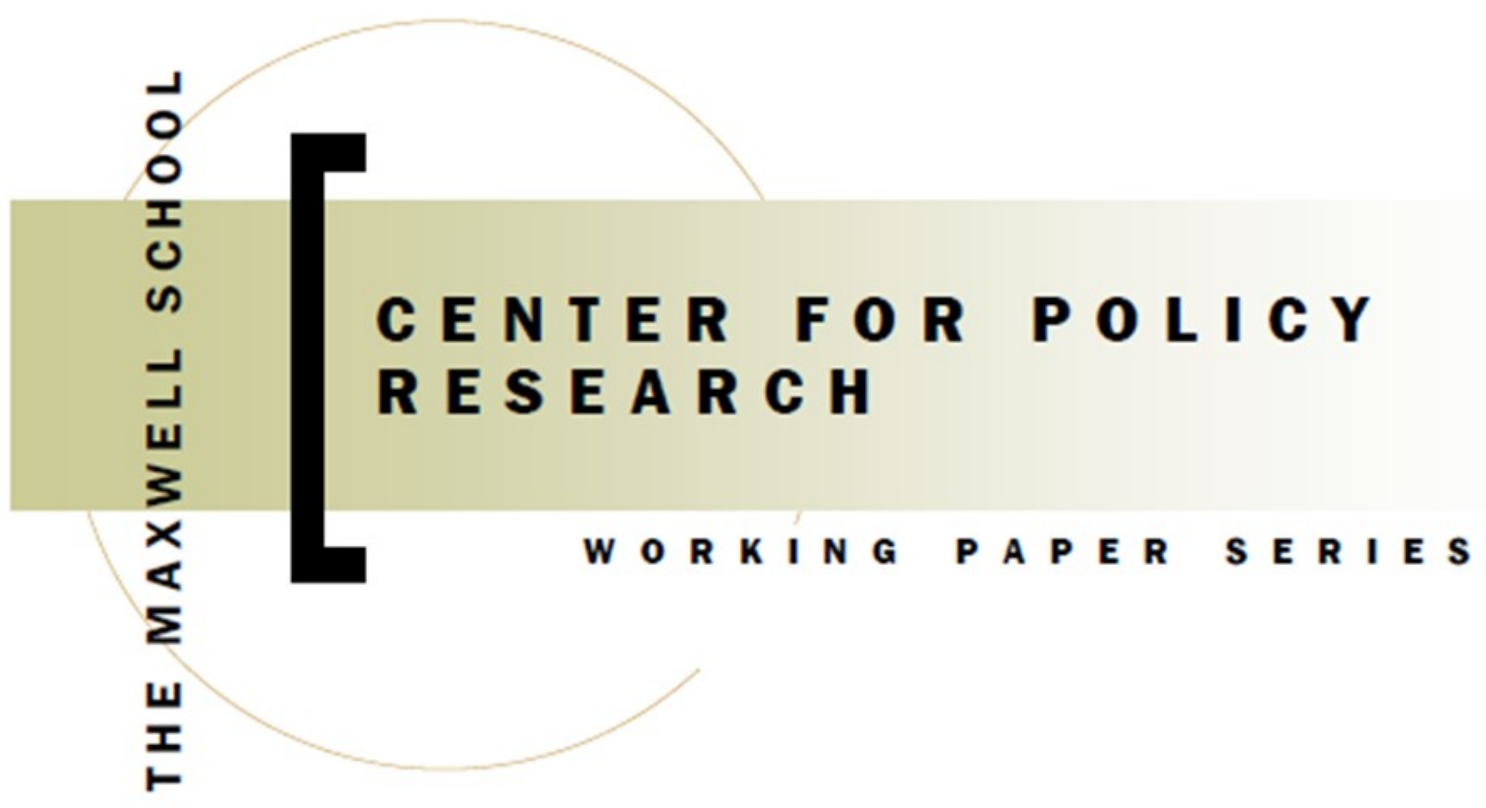

\title{
Welfare Reform and Children's Health
}

Badi H. Baltagi and Yin-Fang Yen

\section{ISSN: $1525-3066$}

426 Eggers Hall

Syracuse University

Syracuse, NY 13244-1020

(315) 443-3114 / email: ctrpo|@syr.edu

Paper No. 172

http://www.maxwell.syr.edu/CPR_Working_Papers.aspx 


\section{CENTER FOR POLICY RESEARCH - Fall 2014}

\section{Leonard M. Lopoo, Director Associate Professor of Public Administration and International Affairs (PAIA)}

\section{Associate Directors}

Margaret Austin

Associate Director

Budget and Administration

John Yinger

Trustee Professor of Economics and PAIA

Associate Director, Metropolitan Studies Program

\section{SENIOR RESEARCH ASSOCIATES}

\begin{tabular}{|c|c|}
\hline Badi H. Baltagi. & Economics \\
\hline Robert Bifulco ....... & ..........PAIA \\
\hline Thomas Dennison . & . PAIA \\
\hline Alfonso Flores-Lagunes . & Economics \\
\hline Sarah Hamersma ............ & ..........PAIA \\
\hline William C. Horrace . & Economics \\
\hline Yilin Hou & .........PAIA \\
\hline Duke Kao ................................ & . Economics \\
\hline Sharon Kioko ........... & ......... PAIA \\
\hline Jeffrey Kubik.... & Economics \\
\hline Yoonseok Lee .... & Economics \\
\hline Amy Lutz.......... & .. Sociology \\
\hline Yingyi Ma... & .. Sociology \\
\hline & \\
\hline
\end{tabular}

Cynthia Morrow ..................................................... Jan Ondrich...................................... Economics John Palmer ................................................... PAIA Eleonora Patacchini ...................................Economics David Popp ................................................... PAIA

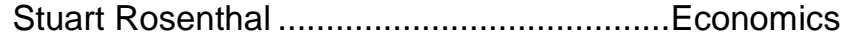
Ross Rubenstein........................................ PAIA Rebecca Schewe .................................................... Amy Ellen Schwartz ........................ PAIA/Economics Perry Singleton..............................Economics

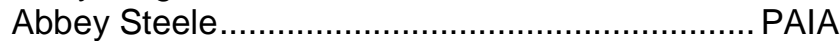
Michael Wasylenko ............................Economics Peter Wilcoxen ..................................................

\section{GRADUATE ASSOCIATES}

Christian Buerger

Emily Cardon

Hannah Dalager

Maidel De La Cruz.

Carlos Diaz.

Vantiel Elizabeth Duncan

Alex Falevich...

Lincoln Groves

Ruby Jennings

Yusun Kim

Bridget Lenkiewicz

Michelle Lofton
PAIA

PAIA

PAIA

PAIA

Economics

PAIA

Economics

PAIA

PAIA

PAIA

PAIA

PAIA
Roberto Martinez

Qing Miao

Nuno Abreu Faro E Mota

Judson Murchie

Sun Jung Oh

Brian Ohl

Laura Rodriquez-Ortiz

Timothy Smilnak

Kelly Stevens

Rebecca Wang

Pengju Zhang

Xirui Zhang
PAIA

PAIA

Economics PAIA

Social Science PAIA

PAIA

PAIA

PAIA

Sociology

Economics

Economics

\section{STAFF}

Kelly Bogart.

Karen Cimilluca.

Kathleen Nasto

Candi Patterson
Administrative Specialist Office Coordinator Administrative Assistant Computer Consultant
Mary Santy. Katrina Wingle.
Administrative Assistant .Administrative Assistant 


\section{Abstract}

This study investigates the effect of the Temporary Aid to Needy Families (TANF) program on children's health outcomes using data from the Survey of Income and Program Participation (SIPP) over the period 1994 to 2005. The TANF policies have been credited with increased employment for single mothers and a dramatic drop in welfare caseload. Our results show that these policies also had a significant effect on various measures of children's medical utilization among low-income families. These health measures include a rating of the child's health status reported by the parents; the number of times that parents consulted a doctor; and the number of nights that the child stayed in a hospital. We compare the overall changes of health status and medical utilization for children with working and nonworking mothers. We find that the child's health status as reported by the parents is affected by the maternal employment status.

\section{JEL No. I1}

Keywords: Maternal Employment; Children's Health; Welfare; Fixed Effects

Badi H. Baltagi, Corresponding author. Department of Economics and Center for Policy Research, Syracuse University, 426 Eggers Hall, Syracuse, NY 13244-1020

Email: bbaltagi @maxwell.syr.edu

Yin-Fang Yen. School of Public Administration, Southwestern University in Finance and Economics, A319 Tongbo Building, Chengdu, Sichuan, 611130, China.

Email: yyf@swufe.edu.cn 


\section{Introduction}

The child's health depends among other things on the amount of time and money the parents spend on their children. Children in higher-income families usually have more nutritious diets and better care than children from low-income families. It is well documented that children in poverty have worse health conditions and school performance, and lower future earnings (see Aber et al., 1997; Currie and Lin, 2007; Case, Lubotsky, and Paxson, 2002; Case, Fertig, and Paxson, 2005; and Currie et al., 2010 to mention a few). Children with working mothers receive less time or attention than those with non-working mothers (Bianchi, 2000; Paxson and Waldfogel, 2002). The impact on children may grow as more mothers in low-income families join the labor force and as possible welfare benefits change after the welfare reform of the late 1990s.

Under the Personal Responsibility and Work Opportunity Reconciliation Act (PRWORA), Temporary Aid to Needy Families (TANF) program replaced Aid to Families with Dependent Children (AFDC) in 1996. To reduce welfare dependency of low-income families, TANF limits the lifetime welfare use and requires work-attached activities. The restrictive TANF policies lead to a dramatic decrease in welfare caseloads (Moffitt, 2003) ${ }^{1}$. The total amount of children covered by AFDC/TANF dropped from 9.3 million in 1992 to 3 million in 2008. Parents left this program because they either found employment or they failed to meet the restrictive requirements. In the latter case, children lose their cash benefits which in turn could affect their health. Parents that obtain jobs, presumably with higher income, can provide better quality food

\footnotetext{
${ }^{1}$ However, Ziliak et al. (2000) suggest that economic conditions may have been the major culprit in the caseload decline.
} 
and care for their children ${ }^{2}$. The worker participation rate among AFDC/TANF families increased from $18.8 \%$ in 1992 to $29.4 \%$ in 2008 , even with a recession in the late 2000 's (DHHS, 1998, 2009). In fact, Grogger (2004) reports higher employment after the implementation of lifetime limits. As a result, children leaving TANF in either of these two scenarios can have different health outcomes.

Studies investigating the change in children's health status after welfare reform are rare. Exceptions are Leonard and Mas (2008) and Dunifon, Hynes, and Peters (2006). Leonard and Mas found that states which imposed shorter time limits on being in welfare had higher infant mortality rates. This was more pronounced for less educated and unmarried women. In contrast, Dunifon, Hynes, and Peters found insignificant effects of welfare reform policies on the child's health status as rated by the parents. One similar study by Gennetian et al. (2010) suggests a modest adverse child health effect of maternal employment due to National Evaluation of Welfare-to-Work Strategies program implemented in the early 1990s.

Our study considers children under age 18 using data from the Survey of Income and Program Participation (SIPP) over the period 1994 to 2005. The medical utilization measures include the number of times that parents consulted a doctor and the number of nights that the child stayed in a hospital. A two-way fixed effects model on individuals and time allow us to control for the unobservable characteristics of the child that are time invariant as well as year effects that are invariant to all children. It is well known that fixed effects may help reduce some of the bias due to sample selection.

\footnotetext{
${ }^{2}$ Empirical studies report mixed results of how a child's health is impacted by maternal employment (see BrooksGunn et al., 2002; and Waldfogel, 2004 to mention a few).
} 
We also consider health insurance and Earned Income Taxes Credit (EITC) in our model. During the welfare reform period, Medicaid was expanded and the State Children’s Health Insurance Program (SCHIP) was introduced to assist the medical care needs of low-income families. Children’s public health insurance coverage rates increased from $14.2 \%$ in 1987 to 23.3\% in 2001 (Cunningham and Kirby, 2004). Children's health and medical care accessibility are affected by health insurance. EITC encourages many low-income single-parent families to participate in the labor force (Hotz and Scholz, 2006; Eissa and Liebman, 1996), and may improve maternal health of low-income families through higher income/socioeconomic status (Evans and Garthwaite, 2014).

Our results show significant changes in children’s medical utilization among low-income families after welfare reform. These measures include the number of times that parents consult a doctor and the number of nights that the child stayed in a hospital. We compare the overall changes of health status and medical utilization for children with working and nonworking mothers. We find that the child's health status as reported by the parents is affected by the maternal employment status. Our results show that children with working mothers increase their doctor consultations while those with nonworking mothers have a significantly higher number of nights in a hospital. In addition, we find that all families are responsive to work requirements and harsh sanction policies.

\section{Welfare Reform in the 1990's}

Before the PRWORA, families receiving AFDC benefits were typically low-income singleparent families with at least one child under 18 years of age. Cash-aid continued until they earned higher income or all the children in the family became 18 years or older. AFDC generated 
work disincentive for low-income female headed families (Moffitt, 1992). In addition, Currie and Cole (1993) argued that it also generated undesired maternal behavior, such as inappropriate prenatal care. To reduce the dependency on welfare programs, TANF mandated several restrictive requirements. The requirements include: (i) lifetime limits, (ii) work-attached activities, (iii) initial sanctions, and (iv) family caps.

The lifetime limits restrict the total cumulative use of TANF to only 60 months in the recipients' lifetime. Families leave TANF when their income is higher than the threshold, and enroll again when their income drops lower than the threshold. If families reach the lifetime limits, they are not able to enroll in TANF again. Similarly, the federal program requires recipients to participate in the labor force within 24 months. If the parents fail to meet this workactivity requirement, their benefits may be partly or fully sanctioned. It is even more challenging for low-income families if the state mandates full-benefit initial sanctions when parents cannot fulfill the first time requirements.

Besides welfare dependency, economists and policy makers also worry about the fertility decision of low-income families. Most welfare programs increase benefits if the family has one additional child. Families may intentionally have additional children due to these benefits. In fact, Robins and Fronstin (1996) find that AFDC benefits increase the birth rate among black and Hispanic unmarried women. To reduce these incentives, families are given zero or partial incremental benefits for an additional child under family caps.

The federal policy is a general guideline of TANF. State governments decide which policy to implement, and how, and when to implement these policies. Each state can modify the restrictions according to their economic situations or concerns. Some states have shorter lifetime 
limits, but no family caps. Two states may both implement immediate work activity requirements, but only one may have full sanction policy. As a result in 2005, 11 states have lifetime limits shorter than 60 months, while four states do not have this mandate. In addition, 43 states require immediate work activities in 2005. The implementation dates also vary by states. Some states enforced state-wide welfare reforms and implemented restrictive waivers before TANF. The waivers resemble the TANF policies, however, with a less comprehensive design. One state may implement part of the four policies along with some other requirements as its waivers. Table 1a presents the number of states ${ }^{3}$ implementing waivers and TANF from 1994 to 1999, and Table 1b presents the number of states implementing policies after 1994. States are counted in both categories at the year that waivers were replaced with TANF. About half of the states implemented waivers prior to TANF. In fact, waivers are not replaced immediately after the PRWORA in 1996. For example, Hawaii adopted waivers in 1997 and replaced it with TANF in the same year. All states implemented TANF between 1996 and 1997. Table 1b shows that almost all states adopt time limits and work requirements, regardless of the duration limits. 22 states adopted family caps and 18 states adopted full initial sanctions in 2005, respectively. The amount of benefits also varies by state and depend on the arrangement of its TANF block grant from the federal government ${ }^{4}$. For example, both Mississippi and Alaska have 60-month lifetime limits in 2005. However, Mississippi has the lowest benefits and Alaska has the highest benefits in the US.

\footnotetext{
${ }^{3}$ This includes 50 U.S. states and Washington D.C.

${ }^{4}$ The lowest maximum benefit for a family of three is $\$ 170$ per month in 2005 , and the median amount is $\$ 379$.
} 


\section{Previous Literature}

Many papers study changes in employment, caseload, and welfare use among low-income families after welfare reform. Grogger $(2003,2004)$ and Moffitt $(2002)$ report an increase in employment among low-income families after the implementation of lifetime limits. The restrictive policies are an important barrier to entry and a primary factor for why families leave the TANF program. Recipients may run out of time limits or are not able to find a job. Around 25 to 40 percent of women who leave welfare do not work. The non-working situation makes it even more economically disadvantageous to them and their children (Moffitt, 2002, 2003; Stuber and Kronebusch, 2004). Parents also tend to be forward-looking. They reduce welfare use when their children are young because time limits restrict the total use of welfare (Grogger, 2004; Swann, 2005). The increase in employment and the decrease in welfare enrollment have marked implications for the health of children in these families.

First, for parents that obtain jobs, and leave welfare, one presumes a higher family income ${ }^{5}$. London et al. (2004) interviewed families that enrolled in welfare programs regarding the changes in their life due to work. These parents reported that work increases self-esteem and instills better self-sufficiency values within children. They also reported that they can afford better medical services and quality of life with higher income. However, these parents stated that they are usually exhausted after work and agreed that going to work decreases the time and energy devoted to their children. Bianchi (2000) also argues that the time that working mothers spent on their children is less than that of unemployed mothers, even though the difference of

\footnotetext{
${ }^{5}$ Grogger (2003) indicates that family income increased over the study period. However, this increase is mainly because of the Earned Income Tax Credit (EITC). Moffitt (2002) finds moderate increments in earnings for women who leave welfare. The gains in earnings exceed the losses of benefits in one or two years after they leave the program. The income is slightly higher with EITC. The main source is from the income change of other family members.
} 
time spent on direct childcare is relatively small. Studies report that there is a greater chance for single working mothers to neglect their children. This includes medical neglect. In fact, the substantiated cases of children maltreatment significantly increased in states with short lifetime limits and tough initial sanctions (Paxson and Waldfogel, 2002, 2003).

Bitler, Gelbach, and Hoynes (2006) find that after welfare reform, more black and Hispanic children live with married parents, or neither parent (likely to be a relative with higher income). In other words, the percentage of children living with an unmarried parent decreases. The results are mixed for white children. They argue that, compared to living with a single parent, children could have better outcomes when they live with a grandparent and no parent. Paxson and Waldfogel (2003) also suggest that it is more likely for children to be sent to out-of-home care (primarily foster care) in states with short lifetime limits, tough initial sanctions, family caps, and immediate work requirements. Conversely, states with more generous benefits are associated with a lower out-of-home care rate. Children may or may not receive proper care depending on the parent's living arrangements. According to Bitler, Gelbach, and Hoynes, children who are sent to out-of-home care may be better off than staying home alone. On the other hand, Gordon et al. (2007) argue that center-based childcare provides less quality than maternal care. Young children in center-based care tend to have more injuries and infectious diseases.

Second, if parents do not obtain a job in time or families run out of time limits, they lose their benefits temporarily or permanently. Their income is likely to be lower than that when they were under welfare. Even with income from other family members and welfare programs, a fraction of these families will still be worse off after they leave TANF (Moffitt, 2002). As a result, these families facing a tougher situation without benefits and sufficient income may not be able to 
provide the same nutritious food or proper care for their children. Studies have shown that children in poverty are more likely to have poor health (Aber et al, 1997; Currie and Lin, 2007).

Combining these two effects, it is not clear whether the net change is a negative or positive effect on children's health and medical utilization after these policy waivers and TANF were implemented. Few studies investigate the welfare reform policy effects on children's health and medical utilization. Dunifon, Hynes, and Peters (2006) studied how changes in welfare reform policies influenced children's well-being via their influence on income, employment, or welfare participation of the parents. They used data from the 1992, 1993 and 1996 panels of SIPP. One of the measures of child well-being was the child's health (but only for children with ages 0-5). This was reported by the child's primary caregiver and is one of the health variables that we use in our study. They argued that if changes in welfare policies increase family income, one may see improvements in child's health. However if changes in welfare policies increase employment without changing income, one may see reductions in child health due to less parental supervision and/or stressful family situation. They argue that their results are inconclusive and do not suggest that welfare reform policies have a uniform, strong effect on the aspects of parenting behavior and child well-being.

Leonard and Mas (2008), on the other hand, showed that infant mortality rates increased in states with shorter lifetime limits. Using the Centers for Disease Control and Prevention (CDC) data covering 1995-2002 and a linear probability model, they found that this effect was larger for blacks than for whites. However, they do warn that time limits did not account for the whole increase in mortality rates. The bad economy in the early 2000's and state differences could also be part of the reasons. 


\section{Data and Methodology}

Our data focuses on children under age 18 in families where parents have at most a high school degree. The lower-educated families are more likely to enroll in welfare programs. We use the SIPP data which consists of several panels ${ }^{6}$. The duration of each panel is between 2.5 to 4 years. We combine these panels into a larger dataset spanning the period 1994 to 2005. A longer duration dataset allows us to investigate long-term health effects, which were not feasible in previous studies that were based upon shorter periods. SIPP collects general individual information with different topical modules every four months. The health module ${ }^{7}$ reports the following three measures of children's health and medical utilization: (i) a health status rating by parents, varying from excellent, very good, good, fair, to poor; (ii) the number of times that parents saw or talked to a doctor or an assistant regarding child health in the past 12 months; and (iii) the number of nights that the child spent in a hospital in the past 12 months. Even though our three measures are related to the child's health, the latter two may also be considered as measures of medical utilization. All of these measures were reported by the primary caregiver. We modified our health status variable to a dummy variable which takes the value one if the child's health is rated as fair or poor and zero otherwise. The child health data was not available prior to $1994^{8}$. SIPP grouped nine states into larger regions before $1996^{9}$. For these larger

\footnotetext{
${ }^{6}$ These include the panels of 1993, 1996, 2001, and 2004.

${ }^{7}$ The health modules started from the last waive of 1992. It is typically surveyed once a year and only one observation per year. Therefore, each child was only interviewed once in the 1992 panel. Fixed effects estimation drops single observation per child. This is why the 1992 panel was dropped from fixed effects estimation. With the various durations of each panel, the average times that a child was interviewed vary from 2, 3.57, 2.77, and 2 in the panels of 1993, 1996, 2001, and 2004, respectively. Even though we understand there may be seam bias in the SIPP data, we prefer to use the corresponding original data of other variables from that month.

${ }^{8}$ The health modules are usually surveyed in the latter half of the year and the first two months of the next year in waves 3,6 , and 9 of each panel. If the survey is taken in the latter half of the year, our measures are mostly impacted by the policies in the same year. However, if the interviews are completed in January and February of the next year, they are combined with the previous year.

${ }^{9}$ The nine states include: Alaska, Idaho, Iowa, Maine, Montana, North Dakota, South Dakota, Vermont, and Wyoming.
} 
regions, we could not determine which interviewee belonged to which state. Therefore, we are left with 41 states and Washington D.C.

Some families have easier access to medical care due to unobservable factors such as distance to hospitals. Each care-giver may evaluate the health status using different standards. Therefore, we employ a two-way fixed effects model with individual and time effects, to control for heterogeneity as well as omission bias. In addition, families with employed mothers may systematically have less time to take care of children, especially for mothers who are not married or belong to a lower socioeconomic status. We split our sample into two subgroups based on the employment status of mothers: mothers who are employed at all time of the year; and mothers who are never employed in that year ${ }^{10}$.

In addition to the employment status of mothers, children need different forms of care at different stages. Young children require lots of attention, but as they grow up, they spend more time outside the home and the maternal employment status becomes less important (Bianchi, 2000). Thus, we expect the effect of welfare reform to be different based on the child's age. We separate the children into three age groups: age 0-6, age 7-12, and age 13-17. Children between the ages of 0-6 are those in need of the most care. Children between the ages of 7-12 are in elementary school, but still need some care regarding their health. Young adults between the ages of 13-17 needing the least care for their minor illness conditions. Grogger (2004) also uses these age groups to examine the welfare use of low-income families after the implementation of time limits. In order to estimate the changes in children's health after welfare reform, we employ a linear interaction two-way fixed effects panel data model described as follows:

\footnotetext{
${ }^{10}$ We do not have a group for those mothers who work for only some months in the full year. The sizes of these groups are too small when we separate these partly-working mothers into two subgroups.
} 


$$
\begin{aligned}
& \text { Health }_{\text {ist }}=\alpha+\beta_{1} \text { Age }_{\text {ist }}+\beta_{2} \text { Waiver }_{\text {st }}+\beta_{3} \text { Waiver }_{\text {st }} * \text { Age }_{\text {ist }} \\
& +\beta_{4} \mathrm{TANF}_{\mathrm{st}}+\beta_{5} \mathrm{TANF}_{\mathrm{st}} * \mathrm{Age}_{\mathrm{ist}}+\beta_{6} \text { Maxben }_{\mathrm{st}}+\beta_{7} \mathrm{EITC}_{\mathrm{it}}+\beta_{8} \mathrm{X}_{\text {ist }} \\
& +\beta_{9} \text { unemployment }_{s t}+\beta_{10} \text { Medicaid coverage } \mathrm{st}_{\mathrm{t}}+\mathrm{u}_{\mathrm{i}}+\mathrm{v}_{\mathrm{t}}+\varepsilon_{\mathrm{it}}
\end{aligned}
$$

where Health ${ }_{\text {ist }}$ is the health measure of child $\mathrm{i}$ in state $\mathrm{s}$ at year $\mathrm{t}$. Waiver $_{\mathrm{st}}$ and $\mathrm{TANF}_{\mathrm{st}}$ denote the welfare reform implementations for state $s$ at time t. They are measured as a proportional dummy which is the share of the year that the policy is implemented in the first year, and equal to one afterwards. With the initial implementation dates, we can match the proportion of families with the month they are interviewed, and calculate the exact proportion of families that are impacted that year. If waivers or TANF are implemented after the interview, the proportional dummy is set equal to zero. Following the argument of Bitler, Gelbach, and Hoynes (2005), we cannot assume that waivers and TANF have the same effect across states and over time. The policy variables only measure the average change after the implementation of waivers and TANF. However, by not turning off Waiver $_{\text {st }}$ to zero after the implementation of TANF, we can identify states having waivers before TANF. Max Benefit ${ }_{s t}$ is the maximum AFDC/TANF benefit for a family of three in state s at time t. EITC $_{i t}$ is the federal maximum EITC credits, given the number of children in the family, at time t. $\mathrm{X}_{\text {ist }}$ controls for individual characteristics, including child's age group, health insurance status (indicators for whether he/she is covered by Medicaid/SCHIP and by private health insurance), and the number of siblings; mother's age, and dummy variables for whether this is a single-parent family and whether the family lives in a metro area. Unemployment $t_{\text {st }}$ is the unemployment rate in state s at time t, and Medicaid 
coverage $_{\text {st }}$ is the Medicaid child coverage rate in state $\mathrm{s}$ at year $\mathrm{t}^{11}$. The standard errors are clustered by states. All the regressions are weighted by the final weights provided by the SIPP.

The reason we included maximum benefits and health insurance coverage in our model is that they are directly beneficial to children. According to Gertler (2004), a more generous benefit is expected to generate a better child health outcome. Medicaid and SCHIP are public health insurance programs for low-income individuals, including children. The threshold for Medicaid is usually more generous than that for the TANF program for most of the states. Most of the children under AFDC/TANF are covered by Medicaid (Medicare and Medicaid Statistical Supplement, 2009). SCHIP is for children in families with incomes higher than the threshold of Medicaid but still considered low-income by normal living standards. The TANF income thresholds are mostly lower than or equal to $100 \%$ of the federal poverty level, but the state Medicaid thresholds for children under age 6 are between 133\% and 275\% of the FPLs in 1997. SCHIP covers children in families with income around 200\% of the FPL in most states. Some states have an income threshold of up to $300 \%$ of the FPL. This direct medical assistance benefits many low-income families, especially those with sick children. As noted by Currie and Gruber (1996), medical utilization of eligible children would increase and their mortality rate decrease with the expansion of Medicaid. Aizer (2007) also suggests that children use more preventive healthcare and their health is improved after enrolling in Medicaid. In a survey study of Currie and Almond (2011), many of the studies indicate that Medicaid expansion is associated with lower mortality rate and fewer preventable hospitalizations. The restrictive requirements of the TANF program may push them out of TANF causing a switch to Medicaid or SCHIP.

\footnotetext{
${ }^{11}$ The Medicaid child coverage rate is equal to the total number of children covered by Medicaid divided by the total number of children under age 21.
} 
Parents may not meet the requirements of this program or run out of the lifetime limits, but are still eligible for Medicaid or SCHIP. Many families may choose to opt out of TANF. Children in low-income families may have better health due to Medicaid or SCHIP. Interestingly, Medicaid is rarely discussed in previous studies on TANF. The state Medicaid child coverage rate is a measure of the expansion in the late 1990s and the generosity of the state government on child health policies.

We also include the state unemployment rate to controls for the effects of the economy ${ }^{12}$. However, the state economy is likely to correlate also with state Medicaid child coverage. More children enroll in Medicaid in a bad economy. Currie and Grogger (2002) argue that if the unemployment rate can perfectly control for state economic conditions, we expect children to have better health with the expansion of Medicaid, holding everything else equal. However, if the unemployment rate cannot perfectly control for state economic conditions, the high Medicaid coverage rate reflects the hardship of low-income families.

EITC is a refundable credit for low-income families, especially those with children. The amount of credit varies by income and the number of children in the family. Studies indicate that EITC encourages single mothers to join the labor force (Eissa and Liebman, 1996; Meyer and Rosenbaum, 2001), but creates a disincentive for married couples (Eissa and Hoynes, 2003). Grogger (2003) and Meyer and Rosenbaum (2001) suggest that ETIC accounts for most of the increase of employment and earnings, and this in turn should have an effect on children's health.

Table 2 presents our summary statistics. The mean of poor/fair health status for all children in lower-educated families is 0.03 , which implies that on the average parents rate their children

\footnotetext{
${ }^{12}$ Ruhm (2000) argues that individuals have healthier habits and weight during recessions, and that the effect of a recession on preventive health care is insignificant.
} 
in excellent/very good/good health. While some parents consult doctors every day for the whole year, the low means of the medical utilization measures indicate that most of the children have only few doctor consultations and few nights of hospital stays. There are substantial differences in the health measures considered between children with working and nonworking mothers. Compared to those with working mothers, children with nonworking mothers are more likely to be reported in poor/fair health, with more doctor consultations and hospital stays. They are also more likely to be younger and have more siblings. $61.3 \%$ of children with working mothers are covered by private health insurance and only 24\% of them enroll in Medicaid/SCHIP. In contrast, only $30.1 \%$ of the children with nonworking mothers are covered by private health insurance while 51\% are in Medicaid/SCHIP.

\section{Results}

Table 3 presents the two-way fixed effect estimates of different measures of health utilization and the child's health rating. The first two columns give estimates of the changes in the probability of whether the child is rated in poor/fair health or not. Columns (3) - (4) give estimates of the changes in doctor consultations. The last two columns show the results of hospital stays. Column (1) indicates that children in states implementing waivers are more likely to be rated as having poor or fair health. The probability increases by 0.023 . Self-reported health condition does not have a significant change after the implementation of TANF. Children who enroll in Medicaid/SCHIP are more likely to be in poor/fair health. Children in a single-parent family are more likely to be rated as having poor/fair health. Families are less likely to rate the child having poor/fair health during a bad economy. This is in line with the study of Ruhm (2000) that suggests health improves during a recession. When we interact the waivers and TANF with age groups in column (2), the probability of being rated as poor/fair health after the 
implementation of waivers remains large but becomes insignificant. The effects of other variables are close to the estimates without age group interactions.

Doctor consultation does not have a significant change after the implementations of waivers and TANF, see column (3). However, when we interact the waiver and TANF with age groups in column (4), the older children increase their doctor consultations by 1.114 times after the implementation of TANF. Children in the youngest age group have fewer doctor consultations, 1.623 times less than the older children. EITC credit has a small but significant effect on doctor consultations. Children with one more sibling have 0.16 fewer times of doctor consultations. Having private and public health insurance increases the doctor consultations by 0.42 and 0.67 times, respectively.

The number of nights spent in a hospital increased significantly after the implementation of TANF, see column (5). With the age group interactions, the increase in hospital stays remains significant in column (6). The number of hospital stays increases by 0.54 nights after the implementation of TANF. However, the hospital stays of children in the youngest age group decreases by 0.59 nights, compared to the oldest children. Children who enroll in Medicaid/SCHIP have 0.148 more nights of hospital stays. Children in single-parent families have 0.089 more nights of hospital stays than those in two-parent families. Similar to doctor consultations, children with older mothers have fewer hospital stays.

The results confirm the hypothesis that children have different medical needs at different growing-up stages. Without the age group interactions, some effects on medical utilization are eliminated. The results in Table 3 suggest that the probability of being rated as having poor/fair health is only weakly associated with the implementations of waivers and TANF. This is 
different from the effect on doctor consultations and hospital stays. This difference may be due to the effect of employment. Children may have the same health condition, but employed parents change their medical utilization because they do not have time. In order to investigate this further, we compare the difference between families with working and nonworking mothers.

Table 4 presents the estimates of the changes in each health measure, for children in different age groups, based on the maternal employment status. Column (1) indicates that children between age 7 and age 12 with working mothers have 1.6 percentage points higher than older children in the probability of being rated as having poor/fair health after the implementation of waivers. The probability increases by 2.1 percentage points after the implementation of TANF. Enrolling in Medicaid/SCHIP increases the probability of being rated as poor/fair health by 1 percentage point. Children with working single mothers are 1.1 percentage points higher. Column (2) shows that children with nonworking mothers are less likely to be rated as having poor/fair health status by 3.1 percentage points after TANF. The cash benefits and the state unemployment rate, on the other hand, have stronger effects. The probability of being rated as having poor/fair health decreases by 0.14 with an increase of benefit by 1000 dollars. Higher unemployment rate is associated with lower probability of poor/fair health status for families with nonworking mothers. Children enrolling in Medicaid are also more likely to be considered as having poor/fair health status.

The number of doctor consultations for children with working mothers are significantly affected by the implementation of TANF, see column (3). In contrast, there is no significant change for those with nonworking mothers, see column (4). However, for children in the youngest age and the second youngest groups, their numbers of doctor consultations decreased by 1.62 and 0.755 , respectively. With an increase of 1000 dollars of maximum benefits and 
EITC maximum credits, doctor consultations dropped by 3.736 and 0.447 , respectively. Children with private and public health insurance have 0.429 and 0.741 times more doctor consultations, respectively. Older mothers consult a doctor more often than younger mothers. None of the effects on doctor consultations is significant for children with nonworking mothers.

In contrast to doctor consultations, the implementations of waivers and TANF affect the number of nights of hospital stays for children with nonworking mothers, see column (6). However, this change is small after TANF for children with working mothers, see column (5). After the implementation of waivers, children with nonworking mothers have 0.312 fewer hospital stays. However, they increase hospital stays by 0.576 nights after TANF. Children in the youngest age group reduce their hospital stays by 0.556 . Other demographic variables are not significant for children with nonworking mothers. On the other hand, for families with working mothers, hospital stays increase by 0.448 after the implementation of TANF. Children enrolling in Medicaid/SCHIP increase the number of nights staying in a hospital, but those living in a metro area lower their hospitalization.

\section{Welfare Reform Policies}

The results from the previous section indicate that one of the possible reasons that children's health respond to the implementations of waivers and TANF is through the maternal employment. Employed mothers usually have higher income and are less likely to enroll in welfare programs. However, some mothers may join the labor force due to the work requirements. Health insurance status is included to control for healthcare accessibility. In this section, we investigate each group separately. Families with working and nonworking mothers may respond to each policy differently. Our reduced form is as follows: 


$$
\begin{aligned}
\text { Health }_{\text {ist }}= & \alpha+\beta_{1} \text { Age }_{\text {ist }}+\beta_{2} \text { Policy }_{\mathrm{st}}+\beta_{3} \text { Policy }_{\mathrm{st}} * \text { Age }_{\text {ist }} \\
& +\beta_{4} \text { Other Policyst }_{\mathrm{st}}+\beta_{5} \text { Other Policy }_{\mathrm{st}}{ }^{*} \text { Age }_{\mathrm{ist}}+\beta_{6} \text { Maxben }_{\mathrm{st}}+\beta_{7} \text { EITC }_{\mathrm{it}} \\
& +\beta_{8} \mathrm{X}_{\mathrm{ist}}+\beta_{9} \text { unemployment }_{\mathrm{st}}+\beta_{10} \text { Medicaid coverage }_{\mathrm{st}}+\mathrm{u}_{\mathrm{i}}+\mathrm{v}_{\mathrm{t}}+\varepsilon_{\mathrm{it}}
\end{aligned}
$$

Policyst denotes the welfare reform policies for state s at time t. This is measured as a proportional dummy which is the share of the year that the policy is implemented. This is done for lifetime limits, work requirements, family caps, and initial sanctions being the full benefits. Other Policyst is the proportional dummies for the other three policies that were implemented at a close time. Other variables are identical to those in the previous model ${ }^{13}$.

Table 5 presents the estimates of the change in health and medical utilization after the implementation of each welfare reform policy. Each panel shows the policy we focus on. The first two columns are the results for the effects on the probability of being rated as poor/fair health. Column (1) suggests that the probabilities of youngest children being rated as having poor/fair health by working mothers decreases by 0.025 , while that of the oldest children increases by 0.024 after the implementation of work requirements. The probability increases by 0.031 after the implementation of the harsh initial sanction. After the time limits and work requirements were implemented, the probability of poor/fair health is lowered by 0.031 and 0.057, respectively, for children with nonworking mothers, see column (2).

Comparing columns (3) and (4), younger children with working mothers have 1.279 times fewer doctor consultations than older children after the implementation of time limits. But the oldest children increase doctor consultation by 0.842 times. They have in general 1.026 more doctor consultations after the implementation of working requirements. Children in the youngest

\footnotetext{
${ }^{13}$ We also ran a regression with all four policies in one model and the results are similar.
} 
age group have 1.219 fewer doctor consultations than older children. Children age 7-12, with working mothers, have 0.682 more doctor consultations than the oldest children. On the other hand, working requirements lower the doctor consultations of children age 0-6 with nonworking mothers by 3.091 times. Family caps are not significantly associated with the effects on doctor consultations.

The last two columns are the results of hospital stays. None of the welfare policies are significant for hospital stays of children with working mothers in Column (5). For children with nonworking mothers, working requirements lower the hospital stays of children age 0-6 with nonworking mothers by 0.784 nights, compared to the oldest children. Children on average have higher hospital stays by 0.595 under family caps. Also, children have 0.387 times fewer hospital stays after the implementation of full-benefit initial sanction.

\section{Discussion}

Welfare reform changes the allocation of time and income in low-income families directly and indirectly. Tables 3 and 4 suggest that these changes have some impact on the child's health and medical utilization measures. Children with working mothers are rated differently in terms of their health status than children with nonworking mothers, after the reform. One possible explanation is that family resources are impacted differently after the welfare reform. Guendelman, Wyn, and Tsai (2000) find children of nonworking low-income parents in California have more doctor visits and lower probability of rating as having poor/fair health than those with working parents. Holl et al (2012) find children with working mothers in Illinois are less likely to have recommended medical visits than those with nonworking mothers. These studies suggest that working parents have less time for children, or it may be harder to ask for a 
leave when children are ill. Employed mothers are more likely to be busier after the reform since the federal policy requires parents to work no less than 30 hours per week in order to remain eligible.

Our results indicate the out-of-home care hypothesis from Bitler, Gelbach, and Hoynes, (2006) and Paxson and Waldfogel (2003) is more plausible for younger children with working mothers because they have more time constraints. Children may have better living conditions with out-of-home care. Children with working mothers are also affected by the policy of a harsh punishment for not meeting the work requirement. This is in line with our finding that maximum AFDC/TANF benefits are negatively associated with the number of doctor consultations for children with working mothers. The earnings of these lower-educated working mothers may still be relatively low. Even for those who leave welfare, their income is similar or only slightly higher than that when they were on welfare (Grogger, 2003; Moffitt, 2002).

On the other hand, for younger children with nonworking mothers, the forward-looking hypothesis from Grogger (2004) and Swann (2005) seems to be relevant. These families may lose this welfare benefit in the future and as a result pay more attention to their health. The reduction in medical utilization of young children may indicate the hardship faced by these families. Hospital stays of children with nonworking mothers increase after the implementation of family caps. One possible explanation is the presence of siblings is beneficial to children's health. Ball et al. (2000) suggest that young children are less likely to have allergic diseases when they are exposed to older siblings or if they are attending day care. This is in line with results that the number of siblings have on health and medical utilization. Not all of which are significant in Tables 3 and 4 . The hardship due to initial sanction also reduces hospital stays of children with nonworking mothers 
The increase in employment may or may not be due to the welfare reform. Meyer and Rosenbaum (2001) suggest that the increase in employment in the 1990s is mainly because of the expansion of EITC, while welfare reform has relatively smaller effects. One may also argue that the increase of medical utilization is because of the expansions of Medicaid and the introduction of SCHIP. We have included indicators of enrolling in private health insurance and Medicaid/SCHIP and the state Medicaid coverage rate in our regression. Our results show that, as in previous literature, children who enroll in Medicaid/SCHIP have more medical utilization, but it is only significant for children with working mothers. The probability of being rated as poor/fair health is higher with Medicaid/SCHIP. This conflicts with the results of Currie and Gruber (1996). One possible explanation is that after having health insurance, parents utilize it more for their children since medical care is more accessible to them. Private health insurance coverage only affects the doctor consultation of children with working mothers. The premium out-of-pocket costs of private health insurance are higher. Shaefer, Grogan, and Pollack (2011) indicate that a reduction of nearly 1500 dollars a year for a child switching from public health insurance to private insurance. The state Medicaid coverage rate is not significant in our regressions.

\section{Conclusion}

Our results indicate that families with working and nonworking families are affected differently by welfare policies. Families with working mothers change health rating and doctor consultation after the implementations of time limits, work requirements, and initial sanction as a harsh punishment. On the other hand, children in families with nonworking mothers are rated to have better health after the welfare reform and increase hospital stays, but we have little evidence 
of a change in doctor consultations. Making low-income families self-dependent may not help the health and the healthcare utilization of children in these families.

Our results have to be tempered by the fact that the health measures used in this study are reported measures by the caregiver and are subject to the usual criticism of such subjective measures. Some researchers may argue that each interviewee values their health and recalls their medical utilization differently, which makes the measures less directly comparable among individuals. However, we alleviate this issue by using individual and time fixed effects.

Of course, our study has limitations. One concern is policy endogeneity. Another is that these policies target employment and comparing working and non-working mothers may be subject to selection bias despite controlling for fixed effects. Last but not least the effects on children's health ratings and medical utilization reported in this study may be due to other factors. We do not claim they are solely due to the effects of the welfare policies considered. 


\section{References}

Aber, J. Lawrence, Neil G. Bennett, Dalton C. Conely, and Jiali Li. 1997. "The Effects of Poverty on Child Health and Development.” Annual Review of Public Health 18: 463-483.

Aizer, Anna. 2007. “Public Health Insurance, Program Take-Up, and Child Health.” The Review of Economics and Statistics 89 (3): 400-415.

Ball, Thomas M. et al. 2000. "Siblings, Day-Care Attendance, and the Risk of Asthma and Wheezing during Childhood.” The New England Journal of Medicine 343: 538-543.

Bianchi, Suzanne M. 2000. "Maternal Employment and Time with Children: Dramatic Change or Surprising Continuity?” Demography 37(4): 401-414.

Bitler, Marianne P., Jonah B. Gelbach, and Hilary W. Hoynes. 2005. "Welfare Reform and Health.” The Journal of Human Resources 40 (2): 309-330.

Bitler, Marianne P., Jonah B. Gelbach, and Hilary W. Hoynes. 2006. "Welfare Reform and Children's Living Arrangements.” The Journal of Human Resources 41 (1): 1-27.

Brooks-Gunn, Jeanne, Wen-Jui Han, and Jane Waldfogel. 2002. "Maternal Employment and Child Cognitive Outcomes in the First Three Years of Life: The NICHD Study of Early Child Care.” Child Development 73 (4): 1052-1072.

Case, Anne, Angela Fertig, and Christina Paxson. 2005. "The Lasting Impact of Childhood Health and Circumstance.” Journal of Health Economics 24: 365-389.

Case, Anne, Darren Lubotsky, and Christina Paxson. 2002. "Economic Status and Health in Childhood: The Origins of the Gradient.” The American Economic Review 92 (5): 1308-1334.

Cunningham, Peter, and James Kirby. 2004. "Children's Health Coverage: A Quarter-Century of Change." Health Affairs 23 (5): 27-38.

Currie, Janet, and Jeffrey Grogger. 2002. "Medicaid Expansions and Welfare Contractions: Offsetting Effects on Prenatal Care and Infant Health?” Journal of Health Economics 21: 313335.

Currie, Janet, and Jonathan Gruber. 1996. "Health Insurance Eligibility, Utilization on Medical Care, and Child Health.” The Quarterly Journal of Economics 111 (2): 431-466.

Currie, Janet, Mark Stabile, Phongsack Manivong, and Leslie L. Ross, 2010. "Child Health and Young Adult Outcomes.” The Journal of Human Resources 45 (3): 517-548.

Currie, Janet, and Nancy Cole. 1993. "Welfare and Child Health: The Link between AFDC Participation and Birth Weight.” The American Economic Review 83 (4): 971-985. 
Currie, Janet, and Wanchuan Lin. 2007. "Chipping Away at Health: More on the Relationship between Income and Child Health.” Health Affairs 26 (2): 331-344.

Currie, Janet, and Douglas Almond. 2011. "Human Capital Development before Ag Five." in Orley Ashenfelter and David Card, editors. Handbook of Labor Economics Vol. 4 Part B Chapter 15: 1513-1486. Elsevier.

Dunifon, Rachel, Kathryn Hynes and H. Elizabeth Peters. 2006. "Welfare reform and child wellbeing.” Children and Youth Services Review 28 (11): 1273-1292.

Eissa, Nada, and Hillary Williamson Hoynes. 2004. "Taxes and the Labor Market Participation of Married Couples: the Earned Income Tax Credit.” Journal of Public Economics 88 (9-10): 1931-1958.

Eissa, Nada, and Jeffery B. Liebman. 1996. "Labor Supply Response to the Earned Income Tax Credit.” The Quarterly Journal of Economics 111 (2): 605-637.

Evans, William N., and Craig L. Garthwaite. 2014. "Giving Mom a Break: The Impact of Higher EITC Payments on Maternal Health.” American Economic Journal: Economic Policy 6 (2): 258290.

Gennetian, Lisa A., Heather D. Hill, Andrew S. London, and Leonard M. Lopoo. 2010. "Mothers Employment and the Health of Low-Income Children.” Journal of Health Economics 29 (3): 353-36.

Gertler, Paul. 2004. "Do Conditional Cash Transfers Improve Child Health? Evidence from PROGRESA’s Control Randomized Experiment.” The American Economic Review 94 (2): 336341.

Gordon, Rachel A., Robert Kaestner, and Sanders Korenman. 2007. "The Effects of Maternal Employment on Child Injuries and Infectious Disease.” Demography 44 (2): 307-333.

Grogger, Jeffrey. 2003. "The Effects of Time Limits, The EITC, and Other Policy Changes on Welfare Use, Work, and Income Among Female-Headed Families." The Review of Economics and Statistics 85 (2): 394-408.

Grogger, Jeffrey. 2004. “Time Limits and Welfare Use.” The Journal of Human Resources 39 (2): 405-424.

Guendelman, Sylvia, Roberta Wyn, and Yi-Wen Tsai. 2000. "Children of Working Low-Income Families in California: Does Parental Work Benefit Children's Insurance Status, Access, and Utilization of Primary Health Care?” Health Services Research 35 (2): 417-441. 
Holl, Jane L., et al. 2012. "Effects of Welfare and Maternal Work on Recommended Preventive Care Utilization Among Low-Income Children.” American Journal of Public Health 102 (12): 2274-2279.

Hotz, V. Joseph, and John Karl Scholz. 2006. "Examining the Effect of the Earned Income Tax Credit on the Labor Market Participation of Families on Welfare.” National Bureau of Economic Research (NBER) Working Paper No. 11968.

Leonard, Jonathan, and Alexandre Mas. 2008. "Welfare Reform, Times Limits, and Infant Health.” Journal of Health Economics 27 (6): 1551-66.

London, Andrew S., Ellen K. Scott, Kathryn Edin, and Vicki Hunter. 2004. "Welfare Reform, Work-Family Tradeoffs, and Children Well-Being.” Family Relations 53 (2): 148-158.

Meyer, Bruce D., and Dan T. Rosenbaum. 2001. "Welfare, the Earned Income Tax Credit, and The Labor Supply of Single Mothers.” The Quarterly Journal of Economics 116 (3): 1063-1114.

Moffitt, Robert. 1992. “Incentive Effects of the U.S. Welfare System: A Review.” Journal of Economic Literature 30 (1): 1-61.

Moffitt, Robert. 2002. "From Welfare to Work: What the Evidence Shows." Policy Brief No. 13. Washington, DC: Brookings Institution.

Moffitt, Robert. 2003. “The Role of Nonfinancial Factors in Exit and Entry in the TANF program.” The Journal of Human Resources 38 (supplement): 1221-1554.

Paxson, Christina, and Jane Waldfogel. 2002. "Work, Welfare, and Child Maltreatment.” Journal of Labor Economics 20 (3): 435-474.

Paxson, Christina, and Jane Waldfogel. 2003. "Welfare Reforms, Family Resources, and Child Maltreatment.” Journal of Policy Analysis and Management 22 (1): 85-113.

Robins, Philip K., and Paul Fronstin. 1996. "Welfare Benefits and Birth Decisions of NeverMarried Women.” Population Research and Policy Review 15 (1): 21-43.

Ruhm, Christopher J. 2000. “Are Recessions Good For Your Health?” The Quarterly Journal of Economics 115 (2): 617-650.

Shaefer, H. Luke, Colleen M. Grogan, and Harold A. Pollack. 2011. "Transitions from Private to Public Health Coverage among Children: Estimating Effects on Out-of Pocket Medical Costs and Health Insurance Premium Costs.” Health Services Research 46 (3): 840-858.

Stuber, Jennifer, and Karl Kronebusch. 2004. "Stigma and Other Determinants of Participation in TANF and Medicaid.” Journal of Policy Analysis and Management 23 (3): 509-530. 
Swann, Christopher A. 2005. "Welfare Reform When Recipients Are Forward-Looking.” The Journal of Human Resources 40 (1): 31-56.

U.S. Department of Health and Human Services, Administration for Children and Families, Office of Planning, Research and Evaluation. 1998. "Temporary Assistance for Needy Families (TANF) Program: First Annual Report to Congress.” Washington, D.C.: U.S. Government Printing Office.

U.S. Department of Health and Human Services, Administration for Children and Families, Office of Planning, Research and Evaluation. 2009. "Temporary Assistance for Needy Families (TANF) Program: Eighth Annual Report to Congress.” Washington, D.C.: U.S. Government Printing Office.

U.S. Department of Health and Human Services, Health Care Financing Administration.2009. "Medicare and Medicaid Statistical Supplement." Baltimore, MD.

Waldfogel, Jane. 2004. "Welfare Reform and the Child Welfare System.” Children and Youth Services Review 26: 919-939.

Ziliak, James P., David N. Figlio, Elizabeth E. Davis, and Laura S. Connolly. 2000. “Accounting for the Decline in AFDC Caseloads: Welfare Reform or the Economy?” The Journal of Human Resources 35 (3): 570-586. 
Table 1a. Number of states implementing waivers and TANF by year

\begin{tabular}{lcccccccccccc}
\hline & 1994 & 1995 & 1996 & 1997 & 1998 & 1999 & 2000 & 2001 & 2002 & 2003 & 2004 & 2005 \\
\hline Waivers & 11 & 19 & 24 & 12 & 0 & 0 & 0 & 0 & 0 & 0 & 0 & 0 \\
TANF & 0 & 0 & 16 & 51 & 51 & 51 & 51 & 51 & 51 & 51 & 51 & 51 \\
\hline
\end{tabular}

Table 1b. Number of states implementing specific policies by year

\begin{tabular}{lcccccccccccc}
\hline & 1994 & 1995 & 1996 & 1997 & 1998 & 1999 & 2000 & 2001 & 2002 & 2003 & 2004 & 2005 \\
\hline Time limits & 1 & 5 & 28 & 48 & 49 & 47 & 47 & 47 & 47 & 47 & 47 & 47 \\
Work requirements & 3 & 8 & 29 & 51 & 51 & 51 & 51 & 51 & 51 & 51 & 51 & 51 \\
Family caps & 3 & 9 & 17 & 21 & 21 & 21 & 22 & 22 & 22 & 23 & 22 & 22 \\
Initial sanctions & 0 & 0 & 6 & 11 & 13 & 12 & 12 & 12 & 13 & 13 & 17 & 18 \\
\hline
\end{tabular}


Table 2. Descriptive Statistics

\begin{tabular}{|c|c|c|c|}
\hline & Full Sample & Working Mother & Nonworking Mothers \\
\hline \multicolumn{4}{|l|}{ Dependent variables: } \\
\hline \multirow[t]{2}{*}{ Poor/fair health status } & 0.035 & 0.024 & 0.049 \\
\hline & $(0.183)$ & $(0.153)$ & $(0.215)$ \\
\hline \multirow[t]{2}{*}{ Number of doctor consultations } & 2.399 & 2.332 & 2.551 \\
\hline & $(6.475)$ & $(6.076)$ & $(7.868)$ \\
\hline \multirow[t]{2}{*}{ Nights of hospital stays } & 0.215 & 0.158 & 0.296 \\
\hline & (3.028) & $(2.348)$ & $(3.716)$ \\
\hline \multicolumn{4}{|l|}{ Independent variables: } \\
\hline \multirow[t]{2}{*}{ Child's age } & 8.428 & 9.283 & 7.735 \\
\hline & (4.959) & $(4.830)$ & (5.019) \\
\hline \multirow[t]{2}{*}{ Age $0-6$} & 0.392 & 0.317 & 0.452 \\
\hline & $(0.488)$ & $(0.465)$ & $(0.498)$ \\
\hline \multirow[t]{2}{*}{ Age 7-12 } & 0.347 & 0.369 & 0.325 \\
\hline & $(0.476)$ & $(0.483)$ & $(0.468)$ \\
\hline \multirow[t]{2}{*}{ Age 13-17 } & 0.261 & 0.313 & 0.223 \\
\hline & $(0.439)$ & $(0.464)$ & $(0.416)$ \\
\hline \multirow[t]{2}{*}{ Number of siblings } & 1.671 & 1.412 & 1.993 \\
\hline & $(1.416)$ & $(1.256)$ & $(1.578)$ \\
\hline \multirow[t]{2}{*}{ Male } & 0.510 & 0.507 & 0.510 \\
\hline & $(0.500)$ & $(0.500)$ & $(0.500)$ \\
\hline \multirow[t]{2}{*}{ White } & 0.736 & 0.741 & 0.756 \\
\hline & $(0.441)$ & $(0.438)$ & $(0.429)$ \\
\hline \multirow[t]{2}{*}{ Black } & 0.205 & 0.206 & 0.177 \\
\hline & $(0.404)$ & $(0.404)$ & $(0.381)$ \\
\hline \multirow[t]{2}{*}{ Covered by private insurance } & 0.446 & 0.613 & 0.301 \\
\hline & $(0.497)$ & $(0.487)$ & $(0.459)$ \\
\hline \multirow[t]{2}{*}{ Covered by Medicaid/SCHIP } & 0.379 & 0.240 & 0.510 \\
\hline & $(0.485)$ & $(0.427)$ & $(0.500)$ \\
\hline \multirow[t]{2}{*}{ Living in a metro area } & 0.766 & 0.760 & 0.774 \\
\hline & $(0.424)$ & $(0.427)$ & $(0.418)$ \\
\hline \multirow[t]{2}{*}{ Single-parent family } & 0.424 & 0.430 & 0.379 \\
\hline & $(0.494)$ & $(0.495)$ & $(0.485)$ \\
\hline \multirow[t]{2}{*}{ Mother’s age } & 34.046 & 35.291 & 33.634 \\
\hline & (7.590) & $(7.131)$ & (7.973) \\
\hline \multirow[t]{2}{*}{ Max benefits (in 1000’s) } & 0.400 & 0.394 & 0.413 \\
\hline & $(0.174)$ & $(0.167)$ & $(0.185)$ \\
\hline \multirow[t]{2}{*}{ Max EITC credits (in 1000’s) } & 3.630 & 3.575 & 3.688 \\
\hline & $(0.674)$ & $(0.708)$ & $(0.632)$ \\
\hline \multirow[t]{2}{*}{ Unemployment } & 5.238 & 5.125 & 5.423 \\
\hline & $(1.033)$ & $(1.037)$ & $(1.011)$ \\
\hline \multirow[t]{2}{*}{ Medicaid coverage } & 25.365 & 25.030 & 25.777 \\
\hline & (7.098) & (7.244) & (6.806) \\
\hline Observations & 57057 & 25318 & 18266 \\
\hline
\end{tabular}

The first number is the mean and the second number in parentheses is the standard deviation. 
Table 3. Fixed Effects Estimates of the Changes in the Child's Health Status and Medical Utilization.

\begin{tabular}{|c|c|c|c|c|c|c|}
\hline \multirow[b]{2}{*}{ VARIABLES } & \multicolumn{2}{|c|}{ Rated as poor/fair health } & \multicolumn{2}{|c|}{ Time of doctor consultations } & \multicolumn{2}{|c|}{ Nights of hospital stays } \\
\hline & $(1)$ & $(2)$ & (3) & (4) & (5) & (6) \\
\hline \multirow[t]{2}{*}{ Waiver } & $0.0230 * *$ & 0.0203 & 0.1750 & 0.2457 & 0.0350 & 0.0227 \\
\hline & $(0.011)$ & $(0.013)$ & $(0.226)$ & $(0.461)$ & $(0.121)$ & $(0.150)$ \\
\hline \multirow[t]{2}{*}{ Waiver*Age 0-6 } & & 0.0008 & & -0.0025 & & -0.0121 \\
\hline & & $(0.010)$ & & $(0.419)$ & & $(0.093)$ \\
\hline \multirow[t]{2}{*}{ Waiver*Age 7-12 } & & 0.0081 & & -0.3427 & & 0.0138 \\
\hline & & $(0.008)$ & & $(0.377)$ & & $(0.088)$ \\
\hline \multirow[t]{2}{*}{ TANF } & -0.0065 & -0.0036 & 0.3076 & $1.1138^{* * *}$ & $0.3138^{* * *}$ & $0.5403 * * *$ \\
\hline & $(0.008)$ & $(0.012)$ & $(0.183)$ & $(0.277)$ & $(0.111)$ & $(0.117)$ \\
\hline \multirow[t]{2}{*}{ TANF*Age 0-6 } & & -0.0052 & & $-1.6227 * * *$ & & $-0.5851 * * *$ \\
\hline & & $(0.012)$ & & $(0.472)$ & & $(0.170)$ \\
\hline \multirow[t]{2}{*}{ TANF*Age 7-12 } & & -0.0017 & & $-0.3918^{*}$ & & 0.0330 \\
\hline & & $(0.007)$ & & $(0.227)$ & & $(0.182)$ \\
\hline \multirow[t]{2}{*}{ Age group 0-6 } & 0.0025 & 0.0069 & -0.3280 & $1.1110^{*}$ & $-0.4130 * * *$ & 0.1266 \\
\hline & $(0.006)$ & $(0.012)$ & $(0.215)$ & $(0.551)$ & $(0.080)$ & $(0.168)$ \\
\hline \multirow[t]{2}{*}{ Age group 7-12 } & -0.0020 & -0.0041 & $-0.4205^{* *}$ & 0.2576 & $-0.2219 * * *$ & -0.1845 \\
\hline & $(0.004)$ & $(0.009)$ & $(0.184)$ & $(0.390)$ & $(0.055)$ & $(0.165)$ \\
\hline \multirow[t]{2}{*}{ Max Benefits } & -0.0364 & -0.0354 & -0.8060 & -0.7462 & -0.0535 & -0.0310 \\
\hline & $(0.040)$ & $(0.039)$ & $(1.687)$ & $(1.714)$ & $(0.736)$ & $(0.751)$ \\
\hline \multirow[t]{2}{*}{ Max EITC credits } & -0.0012 & -0.0011 & $-0.3142^{* *}$ & $-0.2808 * *$ & -0.0320 & -0.0208 \\
\hline & $(0.005)$ & $(0.005)$ & $(0.139)$ & $(0.136)$ & $(0.057)$ & $(0.059)$ \\
\hline \multirow[t]{2}{*}{ Number of siblings } & -0.0028 & -0.0027 & $-0.1932 * *$ & $-0.1605^{* *}$ & -0.0347 & -0.0212 \\
\hline & $(0.003)$ & $(0.004)$ & $(0.076)$ & $(0.073)$ & $(0.027)$ & $(0.027)$ \\
\hline \multirow[t]{2}{*}{ Private health insurance } & 0.0001 & 0.0001 & $0.4193^{* * *}$ & $0.4203^{* * *}$ & 0.0507 & 0.0520 \\
\hline & $(0.004)$ & $(0.004)$ & $(0.137)$ & $(0.135)$ & $(0.034)$ & $(0.033)$ \\
\hline \multirow[t]{2}{*}{ Medicaid/SCHIP } & $0.0159 * * *$ & $0.0159 * * *$ & $0.6923 * * *$ & $0.6709 * * *$ & $0.1558 * *$ & $0.1476^{*}$ \\
\hline & $(0.005)$ & $(0.005)$ & $(0.088)$ & $(0.085)$ & $(0.075)$ & $(0.073)$ \\
\hline \multirow[t]{2}{*}{ Living in metro area } & -0.0033 & -0.0032 & 0.4322 & 0.4402 & -0.1719 & -0.1682 \\
\hline & $(0.010)$ & $(0.010)$ & $(0.350)$ & $(0.349)$ & $(0.226)$ & $(0.226)$ \\
\hline \multirow[t]{2}{*}{ Single-parent family } & $0.0094 *$ & $0.0093^{*}$ & 0.0141 & 0.0035 & $0.0937^{*}$ & $0.0889 *$ \\
\hline & $(0.005)$ & $(0.005)$ & $(0.222)$ & $(0.225)$ & $(0.050)$ & $(0.049)$ \\
\hline \multirow[t]{2}{*}{ Mother's age } & 0.0064 & 0.0064 & 0.0422 & 0.0384 & -0.0088 & -0.0096 \\
\hline & $(0.004)$ & $(0.004)$ & $(0.151)$ & $(0.150)$ & $(0.010)$ & $(0.010)$ \\
\hline \multirow[t]{2}{*}{ State unemployment rate } & $-0.0061^{*}$ & $-0.0062 *$ & 0.0733 & 0.0497 & 0.0431 & 0.0354 \\
\hline & $(0.004)$ & $(0.004)$ & $(0.150)$ & $(0.149)$ & $(0.042)$ & $(0.044)$ \\
\hline State Medicaid coverage rate & 0.0001 & 0.0001 & -0.0138 & -0.0125 & $-0.0168 * *$ & $-0.0165 * *$ \\
\hline
\end{tabular}




\begin{tabular}{lcccccc} 
& $(0.000)$ & $(0.000)$ & $(0.012)$ & $(0.012)$ & $(0.008)$ & $(0.008)$ \\
Observations & & & & & & \\
R-squared & 56,648 & 56,648 & 56,007 & 56,007 & 56,007 & 56,007 \\
Number of id & 0.003 & 0.003 & 0.004 & 0.006 & 0.003 & 0.004 \\
\hline
\end{tabular}

Note: Max benefit and max EITC credits are measured in thousands. Standard errors are clustered at the state level

* Significant at $10 \%$.

** Significant at $5 \% . \quad \quad * * *$ Significant at $1 \%$. 
Table 4. Fixed Effects Estimates of the Changes in the Child's Health by Maternal Employment Status

\begin{tabular}{|c|c|c|c|c|c|c|}
\hline \multirow[b]{3}{*}{ VARIABLES } & \multicolumn{2}{|c|}{ Rated as poor/fair health } & \multicolumn{2}{|c|}{ Time of doctor consultations } & \multicolumn{2}{|c|}{ Nights of hospital stays } \\
\hline & $\begin{array}{l}\text { Working } \\
\text { Mothers }\end{array}$ & $\begin{array}{c}\text { Nonworking } \\
\text { Mothers }\end{array}$ & $\begin{array}{l}\text { Working } \\
\text { Mothers }\end{array}$ & $\begin{array}{c}\text { Nonworking } \\
\text { Mothers }\end{array}$ & $\begin{array}{l}\text { Working } \\
\text { Mothers }\end{array}$ & $\begin{array}{c}\text { Nonworking } \\
\text { Mothers }\end{array}$ \\
\hline & $(1)$ & $(2)$ & (3) & (4) & (5) & $(6)$ \\
\hline \multirow[t]{2}{*}{ Waiver } & 0.0638 & -0.0052 & 0.7432 & -1.5424 & 0.1676 & $-0.3116 *$ \\
\hline & $(0.044)$ & $(0.025)$ & $(0.460)$ & (1.498) & $(0.219)$ & $(0.184)$ \\
\hline \multirow[t]{2}{*}{ Waiver*Age 0-6 } & -0.0027 & 0.0147 & -0.4869 & 0.9667 & 0.1912 & 0.0027 \\
\hline & $(0.013)$ & $(0.031)$ & $(0.471)$ & $(0.906)$ & $(0.134)$ & $(0.148)$ \\
\hline \multirow[t]{2}{*}{ Waiver*Age 7-12 } & $0.0157 *$ & 0.0238 & -0.1827 & 0.0405 & 0.1236 & 0.0863 \\
\hline & $(0.008)$ & $(0.024)$ & $(0.384)$ & $(0.469)$ & $(0.096)$ & $(0.126)$ \\
\hline \multirow[t]{2}{*}{ TANF } & $0.0213^{* *}$ & $-0.0313^{*}$ & $0.8251 *$ & 0.9607 & $0.4880^{* *}$ & $0.5763 * * *$ \\
\hline & $(0.009)$ & $(0.018)$ & $(0.441)$ & $(0.642)$ & $(0.212)$ & $(0.204)$ \\
\hline \multirow[t]{2}{*}{ TANF*Age 0-6 } & -0.0109 & 0.0091 & $-1.6200 * * *$ & -1.1288 & -0.1674 & $-0.5558 * *$ \\
\hline & $(0.010)$ & $(0.017)$ & $(0.517)$ & $(0.982)$ & $(0.223)$ & $(0.271)$ \\
\hline \multirow[t]{2}{*}{ TANF*Age 7-12 } & -0.0051 & -0.0147 & $-0.7549 * *$ & 0.4156 & 0.0635 & 0.2170 \\
\hline & $(0.011)$ & $(0.014)$ & $(0.340)$ & $(0.441)$ & $(0.219)$ & $(0.323)$ \\
\hline \multirow[t]{2}{*}{ Age group 0-6 } & 0.0079 & -0.0087 & $1.4987 * * *$ & 0.1528 & -0.1305 & -0.0563 \\
\hline & $(0.012)$ & $(0.033)$ & $(0.436)$ & $(0.923)$ & $(0.222)$ & $(0.256)$ \\
\hline \multirow[t]{2}{*}{ Age group 7-12 } & -0.0071 & 0.0009 & 0.3533 & -0.6810 & -0.2336 & $-0.4381^{*}$ \\
\hline & $(0.010)$ & $(0.024)$ & $(0.368)$ & $(0.442)$ & $(0.169)$ & $(0.237)$ \\
\hline \multirow[t]{2}{*}{ Max Benefits } & 0.1041 & $-0.1427 *$ & $-3.7355^{*}$ & 8.4787 & -0.0851 & 0.8444 \\
\hline & $(0.076)$ & $(0.079)$ & $(2.134)$ & (7.321) & $(2.723)$ & $(1.016)$ \\
\hline \multirow[t]{2}{*}{ Max EITC credits } & -0.0041 & -0.0085 & $-0.4469 * *$ & -0.1135 & -0.1615 & 0.0452 \\
\hline & $(0.005)$ & $(0.011)$ & $(0.196)$ & $(0.350)$ & $(0.103)$ & $(0.157)$ \\
\hline \multirow[t]{2}{*}{ Number of siblings } & -0.0027 & -0.0012 & -0.0828 & -0.1960 & 0.0433 & -0.1026 \\
\hline & $(0.003)$ & $(0.006)$ & $(0.105)$ & $(0.170)$ & $(0.057)$ & $(0.073)$ \\
\hline \multirow[t]{2}{*}{ Private health insurance } & -0.0016 & -0.0062 & $0.4291 * * *$ & 0.3136 & 0.0114 & 0.0475 \\
\hline & $(0.006)$ & $(0.007)$ & $(0.144)$ & $(0.354)$ & $(0.052)$ & $(0.103)$ \\
\hline \multirow[t]{2}{*}{ Medicaid/SCHIP } & $0.0097 *$ & $0.0241^{* * *}$ & $0.7409 * * *$ & 0.3563 & $0.3362 * *$ & 0.1140 \\
\hline & $(0.005)$ & $(0.008)$ & $(0.190)$ & $(0.301)$ & $(0.135)$ & $(0.068)$ \\
\hline \multirow[t]{2}{*}{ Living in metro area } & -0.0204 & 0.0155 & -0.0840 & 1.3868 & $-0.6530 *$ & -0.0028 \\
\hline & $(0.021)$ & $(0.020)$ & $(0.340)$ & $(1.258)$ & $(0.375)$ & $(0.154)$ \\
\hline \multirow[t]{2}{*}{ Single-parent family } & $0.0112^{* *}$ & 0.0046 & 0.2548 & -1.0411 & 0.1030 & 0.2315 \\
\hline & $(0.005)$ & $(0.024)$ & $(0.291)$ & $(0.902)$ & $(0.098)$ & $(0.160)$ \\
\hline \multirow[t]{2}{*}{ Mother's age } & -0.0014 & 0.0130 & $0.1033^{* * *}$ & -0.0495 & 0.0101 & -0.0336 \\
\hline & $(0.002)$ & $(0.017)$ & $(0.029)$ & $(0.495)$ & $(0.008)$ & $(0.035)$ \\
\hline State unemployment rate & 0.0008 & $-0.0189 * *$ & -0.3095 & 1.0193 & -0.0025 & 0.1918 \\
\hline
\end{tabular}




\begin{tabular}{lcccccc} 
& $(0.004)$ & $(0.009)$ & $(0.187)$ & $(0.688)$ & $(0.099)$ & $(0.121)$ \\
State Medicaid coverage rate & 0.0005 & 0.0000 & 0.0109 & -0.0329 & -0.0102 & -0.0193 \\
& $(0.001)$ & $(0.001)$ & $(0.019)$ & $(0.036)$ & $(0.006)$ & $(0.017)$ \\
& & & & & & \\
Observations & 25,178 & 18,112 & 24,951 & 17,818 & 24,951 & 17,818 \\
R-squared & 0.003 & 0.006 & 0.005 & 0.009 & 0.005 & 0.006 \\
Number of id & 11,785 & 8,904 & 11,732 & 8,862 & 11,732 & 8,862 \\
\hline
\end{tabular}

Note: Max benefit and max EITC credits are measured in thousands. Standard errors are clustered at the state level
* Significant at 10\%.
** Significant at $5 \%$.
*** Significant at $1 \%$. 
Table 5. Fixed Effects Estimates of the Changes in the Child's Health after the Implementations of Welfare Reform Policies by Maternal Employment Status

\begin{tabular}{|c|c|c|c|c|c|c|}
\hline \multirow{3}{*}{ VARIABLES } & \multicolumn{2}{|c|}{ Rated as poor/fair health } & \multicolumn{2}{|c|}{ Time of doctor consultations } & \multicolumn{2}{|c|}{ Nights of hospital stays } \\
\hline & $\begin{array}{l}\text { Working } \\
\text { Mothers }\end{array}$ & $\begin{array}{c}\text { Nonworking } \\
\text { Mothers }\end{array}$ & $\begin{array}{l}\text { Working } \\
\text { Mothers }\end{array}$ & $\begin{array}{l}\text { Nonworking } \\
\text { Mothers }\end{array}$ & $\begin{array}{l}\text { Working } \\
\text { Mothers }\end{array}$ & $\begin{array}{l}\text { Nonworking } \\
\text { Mothers }\end{array}$ \\
\hline & $(1)$ & $(2)$ & (3) & $(4)$ & (5) & $(6)$ \\
\hline \multicolumn{7}{|l|}{ Panel 1} \\
\hline Time limits & $\begin{array}{l}0.0052 \\
(0.007)\end{array}$ & $\begin{array}{c}-0.0306 * \\
(0.016)\end{array}$ & $\begin{array}{c}0.8420^{*} \\
(0.495)\end{array}$ & $\begin{array}{l}0.4468 \\
(0.419)\end{array}$ & $\begin{array}{l}-0.0063 \\
(0.165)\end{array}$ & $\begin{array}{l}0.4095 \\
(0.249)\end{array}$ \\
\hline Time limits*Age 0-6 & $\begin{array}{l}0.0034 \\
(0.011)\end{array}$ & $\begin{array}{l}0.0118 \\
(0.018)\end{array}$ & $\begin{array}{c}-1.2791 * \\
(0.669)\end{array}$ & $\begin{array}{l}-1.3353 \\
(1.558)\end{array}$ & $\begin{array}{l}0.1305 \\
(0.167)\end{array}$ & $\begin{array}{l}-0.4944 \\
(0.336)\end{array}$ \\
\hline Time limits*Age 7-12 & $\begin{array}{l}0.0016 \\
(0.011)\end{array}$ & $\begin{array}{l}-0.0034 \\
(0.009)\end{array}$ & $\begin{array}{l}-0.7752 \\
(0.497)\end{array}$ & $\begin{array}{l}0.4681 \\
(0.316)\end{array}$ & $\begin{array}{l}0.0887 \\
(0.135)\end{array}$ & $\begin{array}{l}-0.0010 \\
(0.146)\end{array}$ \\
\hline \multicolumn{7}{|l|}{ Panel 2} \\
\hline Work req. & $\begin{array}{c}0.0239 * \\
(0.013)\end{array}$ & $\begin{array}{c}-0.0572 * * \\
(0.023)\end{array}$ & $\begin{array}{l}1.0262 * \\
(0.584)\end{array}$ & $\begin{array}{l}-0.2141 \\
(0.756)\end{array}$ & $\begin{array}{l}0.2808 \\
(0.322)\end{array}$ & $\begin{array}{l}0.1473 \\
(0.288)\end{array}$ \\
\hline Work req.*Age 0-6 & $\begin{array}{c}-0.0253^{*} \\
(0.015)\end{array}$ & $\begin{array}{l}0.0025 \\
(0.026)\end{array}$ & $\begin{array}{c}-1.2185 * \\
(0.671)\end{array}$ & $\begin{array}{c}-3.0913 * \\
(1.734)\end{array}$ & $\begin{array}{l}-0.0537 \\
(0.219)\end{array}$ & $\begin{array}{c}-0.7840 * * \\
(0.337)\end{array}$ \\
\hline Work req.*Age 7-12 & $\begin{array}{l}-0.0183 \\
(0.015)\end{array}$ & $\begin{array}{l}0.0008 \\
(0.023)\end{array}$ & $\begin{array}{l}-0.6414 \\
(0.489)\end{array}$ & $\begin{array}{l}0.6757 \\
(0.643)\end{array}$ & $\begin{array}{l}0.2030 \\
(0.225)\end{array}$ & $\begin{array}{l}0.1286 \\
(0.338)\end{array}$ \\
\hline \multicolumn{7}{|l|}{ Panel 3} \\
\hline Family caps & $\begin{array}{l}-0.0006 \\
(0.009)\end{array}$ & $\begin{array}{l}0.0012 \\
(0.025)\end{array}$ & $\begin{array}{l}-0.3111 \\
(0.287)\end{array}$ & $\begin{array}{l}1.2249 \\
(0.778)\end{array}$ & $\begin{array}{l}-0.2380 \\
(0.177)\end{array}$ & $\begin{array}{c}0.5953^{* *} \\
(0.283)\end{array}$ \\
\hline Family caps*Age 0-6 & $\begin{array}{l}0.0049 \\
(0.009)\end{array}$ & $\begin{array}{l}0.0114 \\
(0.024)\end{array}$ & $\begin{array}{l}-0.2933 \\
(0.447)\end{array}$ & $\begin{array}{l}0.6714 \\
(0.794)\end{array}$ & $\begin{array}{l}0.0122 \\
(0.142)\end{array}$ & $\begin{array}{l}0.0187 \\
(0.120)\end{array}$ \\
\hline Family caps*Age 7-12 & $\begin{array}{l}0.0076 \\
(0.008)\end{array}$ & $\begin{array}{l}0.0046 \\
(0.020)\end{array}$ & $\begin{array}{l}0.3535 \\
(0.359)\end{array}$ & $\begin{array}{l}-0.5976 \\
(0.370)\end{array}$ & $\begin{array}{l}0.0845 \\
(0.105)\end{array}$ & $\begin{array}{l}-0.0700 \\
(0.138)\end{array}$ \\
\hline \multicolumn{7}{|l|}{ Panel 4} \\
\hline Initial sanction & $\begin{array}{l}0.0018 \\
(0.010)\end{array}$ & $\begin{array}{l}0.0244 \\
(0.035)\end{array}$ & $\begin{array}{l}0.0029 \\
(0.329)\end{array}$ & $\begin{array}{l}0.4321 \\
(0.673)\end{array}$ & $\begin{array}{l}-0.3154 \\
(0.223)\end{array}$ & $\begin{array}{c}-0.3865^{*} \\
(0.214)\end{array}$ \\
\hline Initial sanction*Age 0-6 & $\begin{array}{c}0.0309 * * \\
(0.014)\end{array}$ & $\begin{array}{l}-0.0241 \\
(0.032)\end{array}$ & $\begin{array}{l}-0.2102 \\
(0.366)\end{array}$ & $\begin{array}{l}-0.8741 \\
(1.151)\end{array}$ & $\begin{array}{l}0.1121 \\
(0.226)\end{array}$ & $\begin{array}{l}0.1455 \\
(0.262)\end{array}$ \\
\hline Initial sanction*Age 7-12 & $\begin{array}{l}0.0004 \\
(0.015)\end{array}$ & $\begin{array}{l}-0.0267 \\
(0.030)\end{array}$ & $\begin{array}{c}0.6823 * * \\
(0.324)\end{array}$ & $\begin{array}{l}0.8164 \\
(0.954)\end{array}$ & $\begin{array}{l}0.1819 \\
(0.156)\end{array}$ & $\begin{array}{l}0.2455 \\
(0.188)\end{array}$ \\
\hline Observations & 25,178 & 18,112 & 24,951 & 17,818 & 24,951 & 17,818 \\
\hline Number of id & 11,785 & 8,904 & 11,732 & 8,862 & 11,732 & 8,862 \\
\hline
\end{tabular}

Note: Other controls in each panel are a proportional dummy of other policy implemented and its interaction with age groups;

maximum benefits for families of three; child's age group, and the number of siblings; mother's age, and dummy variables for whether it is a single-parent family and the family lives in a metro area; state unemployment rates and state Medicaid 
coverage rate. Max benefit and max EITC credits are measured in thousands. Standard errors are clustered at the state level.

* Significant at $10 \% . \quad$ ** Significant at $5 \%$. $\quad * * *$ Significant at $1 \%$. 